\title{
THE SOCIOECONOMIC CONDITIONS OF ONLINE TAXI DRIVER FAMILIES DURING THE COVID-19 PANDEMIC IN JAKARTA GREATER AREA
}

\author{
Renny Nurhasana ${ }^{\left.183^{*}\right)}$, Mihoko Matsuyuki², Chotib Hasan ${ }^{1}$, Ni Made Shellasih ${ }^{3}$, Fadhilah \\ Rizky Ningtyas ${ }^{3}$, Irene Fitrinitia ${ }^{4}$, Toshiki Negama ${ }^{4}$, Shoya Kuwayama ${ }^{4}$ \\ ${ }^{1}$ Urban Studies Program, School of Strategic and Global Studies, \\ Universitas Indonesia, Jakarta 10430, Indonesia \\ 2Institute of Urban Innovation, Yokohama National University, Yokohama 240-8501, Jepang \\ ${ }^{3}$ Center for Social Security Studies, Universitas Indonesia, Jakarta 10430, Indonesia \\ ${ }^{4}$ Graduate School of Urban Innovation, Yokohama National University, Yokohama 240-8501, Jepang
}

${ }^{*}$ E-mail: rennynurhasana@ui.ac.id

\begin{abstract}
The Covid-19 pandemic affects almost all aspects of human life, from the education, transportation, political and economic sectors. Online taxi drivers are the informal sector that has been economically impacted by a decline in income. This study aims to determine the impact of the Covid-19 pandemic on the socio-economic aspects of the resilience of online taxi drivers since the implementation of Large-Scale Social Restrictions (LSSR) as regulated in Governor Special Capital Region Regulation of Jakarta No. 33/2020. The regulation made them experience a decrease in the number of passengers, thus affecting their income. This study uses a qualitative model with a case study design. Data collection was carried out by focus group discussions and in-depth interviews with a total of 4 informants obtained from purposive sampling, then analyzed using content analysis. They experienced a significant decrease in income of up to 60-70 percent per day, compared to before the pandemic. The decline in income and recommendations for social distancing affect the socio-economic aspects of family resilience from online taxi drivers as informal sectors. Therefore, they must look for other income alternatives. Therefore, they need various alternative jobs and assistance.
\end{abstract}

Keywords: Covid-19, Jakarta greater area, LSSR, online taxi, socio-economic impact

\section{Kondisi Sosial Ekonomi Keluarga Pengemudi Ojek Daring (Online) pada Masa Pandemi Covid-19 di Jabodetabek}

\begin{abstract}
Abstrak
Pandemi Covid-19 memengaruhi hampir semua aspek kehidupan manusia, baik dari sektor pendidikan, transportasi, politik, maupun ekonomi. Pengemudi ojek daring (online) merupakan sektor informal yang terkena dampak ekonomi dengan adanya penurunan pendapatan. Penelitian ini bertujuan untuk mengetahui dampak pandemi Covid-19 terhadap aspek sosial ekonomi ketahanan keluarga pengemudi ojek daring, terutama sejak diberlakukannya Pembatasan Sosial Skala Besar (PSBB) sebagaimana diatur dalam Peraturan Gubernur Daerah Khusus Ibukota Jakarta No. 33/2020. Regulasi tersebut telah membuat pengemudi ojek daring mengalami penurunan jumlah penumpang sehingga memengaruhi pendapatan mereka. Penelitian ini menggunakan model kualitatif dengan desain studi kasus. Pengambilan data dilakukan dengan diskusi terfokus dan wawancara mendalam dengan jumlah 4 informan yang diperoleh dari sampel purposif, kemudian dianalisis menggunakan analisis isi. Mereka mengalami penurunan pendapatan yang signifikan hingga 60-70 persen per hari, dibandingkan sebelum pandemi. Penurunan pendapatan dan anjuran pembatasan sosial memengaruhi aspek sosial ekonomi ketahanan keluarga dari para pengemudi ojek daring sebagai sektor informal. Pengemudi ojek daring harus mencari alternatif penghasilan lain. Oleh karena itu, mereka membutuhkan berbagai alternatif pekerjaan dan bantuan.
\end{abstract}

Kata kunci: Covid-19, dampak sosial-ekonomi, Jabodetabek, ojek daring (online), PSBB

\section{INTRODUCTION}

The Indonesian government has issued an emergency status due to Coronavirus Disease (Covid-19) starting February 29, 2020 (Iswari, Saragi, Sirait, \& Putra, 2020). According to the Ministry of Health, Republic of Indonesia
(2020), the number of positive cases of Covid19 in Indonesia as of October 2020 has reached 300,000 cases, and it was continued to increase. The Covid-19 pandemic affects almost all aspects of human life, including education, transportation, politics, and the economic sector (Ratu, 2020). In breaking the 
chain of transmission of Covid-19, the government has made several efforts, including the implementation of Large-Scale Social Restrictions (LSSR). Implementing the LSSR is also regulated in the Governor Special Capital Region Regulation of Jakarta Number 33/2020 (The Governor Special Capital Region of Jakarta, 2020). However, various socioeconomic problems also arise and immediately impact society (Iswari, Saragi, Sirait, \& Putra, 2020). One of the occupational professions affected by this socio-economic impact is online taxi drivers, both motorbike and car drivers.

Online taxi drivers are the informal sector that is currently developing in Indonesia (Suprayogaswara, 2017). The Indonesian TwoWheeled Action Association (Gabungan Aksi Roda Dua/GARDA) estimates that more than 4 million online taxi drivers are scattered throughout Indonesia. Jakarta has an estimated 1 million mobiles in the Jakarta Greater Area (Kumparan, 2020). The Regulation of the Governor of the Special Capital Region of Jakarta Number $33 / 2020$ is written that "application-based two-wheeled transportation is limited to the use of goods only." Implementing the LSSR certainly causes online taxi drivers who carry two-wheeled vehicles to experience a decrease in income (Iswari, Saragi, Sirait, \& Putra, 2020). Also, online taxi drivers who carry four-wheeled cars are limited in the number of passengers. Therefore, it was affected drivers because their income depends on passengers.

Eddy and Harahap (2020) show that there has been a decrease in the number of receipts (IDR) of online taxi drivers due to the Covid-19 pandemic ranging from $5.3-87.5$ percent, with an average value of 58.14 percent. Another study shows that the average monthly income of online taxi drivers is higher than the average minimum wage before the pandemic (Iswari et al., 2020). The decrease in income due to this regulation impacted online taxi driver families' resilience. Family resilience is identified as various aspects aimed at individual development in the family. The Central Bureau of Statistics and Ministry of Women's Empowerment and Child Protection/KPPPA (2016) stated that family resilience has several dimensions, including physical resilience consisting of health condition and food adequacy, and economic resilience consisting of family income per capita, family savings, and health insurance, financing capability and continuity of children's education, and homeownership. KPPPA's family resilience indicators also share similarities with Kasdi and Saifudin
(2020) research that viewed family resilience from gender partnerships, health and security, economic conditions, socio-psychological resilience, and socio-cultural resilience. Rahmadana and Sagala (2020) identified family resilience during the Covid-19 pandemic through social demographics, primary income sources, income, and access to food sources, access to essential services (health, transportation, clean water, electricity, and internet), social safety nets, assets, adaptive capacity, and stability. The level of family welfare that affects the family's resilience also makes researchers curious to find out more about the impact of Covid-19, which affects online drivers' income on every dimension, including economic resilience and physical resilience of online driver families.

Previous studies show economics affected by the Covid-19 pandemic, both the formal and informal sectors (Fahlefi, Ahmad, \& Rizal 2020; Dewi, Magdalena, Ariska, Setiyawati, \& Rumboirusi, 2020; Ngadi, Meliana, \& Purba, 2020). However, the study about the online transportation sub-sector is still lacking. Online transportation delivers passengers, goods, and food (Eddy \& Harahap, 2020; Farida, Tarmizi, \& November, 2016). The number of online taxi drivers is high in Indonesia, including Jakarta, about 20 percent of Jakarta's total workforce (Central Statistics Agency DKI Jakarta Province, 2020). If the LSSR policy is enforced for an extended period, it will affect their work and decrease their income. Studies of the Covid-19 pandemic impact on online taxi drivers' income are still very few. Therefore, it is important to elaborate on the impact of socioeconomic indicators on family resilience dimensions. A study of the socio-economic conditions of online transportation drivers during the Covid-19 pandemic through the family resilience approach is needed. In addition, the condition of family resilience in the community is one of the issues that support the government's national development. Family is the key to solve various problems of the nation because the family has a crucial role in its participation in a country (Tridianto 2021). This research aims to identify the impact of Covid-19 on the dimensions of family economic resilience, including family income per capita, financing capability, continuity of children's education, family savings, family health insurance, and home-ownership online taxi drivers. Second, to identify the impact of Covid19 on the dimensions of family physical resilience includes food adequacy and nutrition for online taxi drivers. Researchers assume that 
these two dimensions are critical to affect other dimensions of family resilience.

\section{METHODS}

This study uses a qualitative approach with a case study design. The study aims to determine the impact of the Covid-19 pandemic on online taxi drivers' socioeconomic conditions in the Jakarta Greater Area (Jabodetabek/JakartaBogor-Depok-Tangerang-Bekasi). Participants in this study were online taxi drivers who took part in FGD before the Covid-19 pandemic in November 2020 to determine how their income increased before and after becoming online taxi drivers. We have recruited participants through purposive sampling. We recruited informants who carried passengers daily or other features in the Jabodetabek. We have determined the sample size by the data saturation, i.e., at the point where no new themes from the participant's experiences emerge. We have obtained 4 (four) participants in the study according to the criteria. During the Covid-19 pandemic on August 8-11, 2020, the data collection was carried out by zoom application (online) interview. The researcher prepared interview questions based on family resilience indicators of the Ministry of Empowerment, Women and Child Protection (KPPPA), Republic of Indonesia, and additional modified questions (Figure 1). Meanwhile, the list of research variables decriobes in Table 1.
Participants submitted their digital signatures to the informed consent. We recorded all interview process via video and audio. The recordings were transcribed verbatim within 24 hours after the interview. For research credibility, transcripts were conducted independently, and findings were compared and discussed by more than one researcher until coding, categories, and themes were reached. We used investigator triangulation to test the data's validity and reliability. The researcher gave verbatim results to the participants to adjust the recordings with the participants' facts.

The data analyzed using content analysis to systematically turn massive amounts of text into a very organized and concise summary of the main results. Analysis of raw data from interviews transcribed verbatim into categories or themes is a further process of data abstraction at each step of the analysis (Erlingsson \& Brysiewicz, 2017). The first step is to re-read the interview transcript to understand it and get the research participants' main ideas. Next, the researcher re-formulates the interview text into smaller units but still retains its meaning (condensation). Then, the coding process answers the actual content seen in the data. Finally, researchers reformulated them into two major themes in this study: economic and physical resilience of online taxi drivers, classified as socioeconomic conditions.

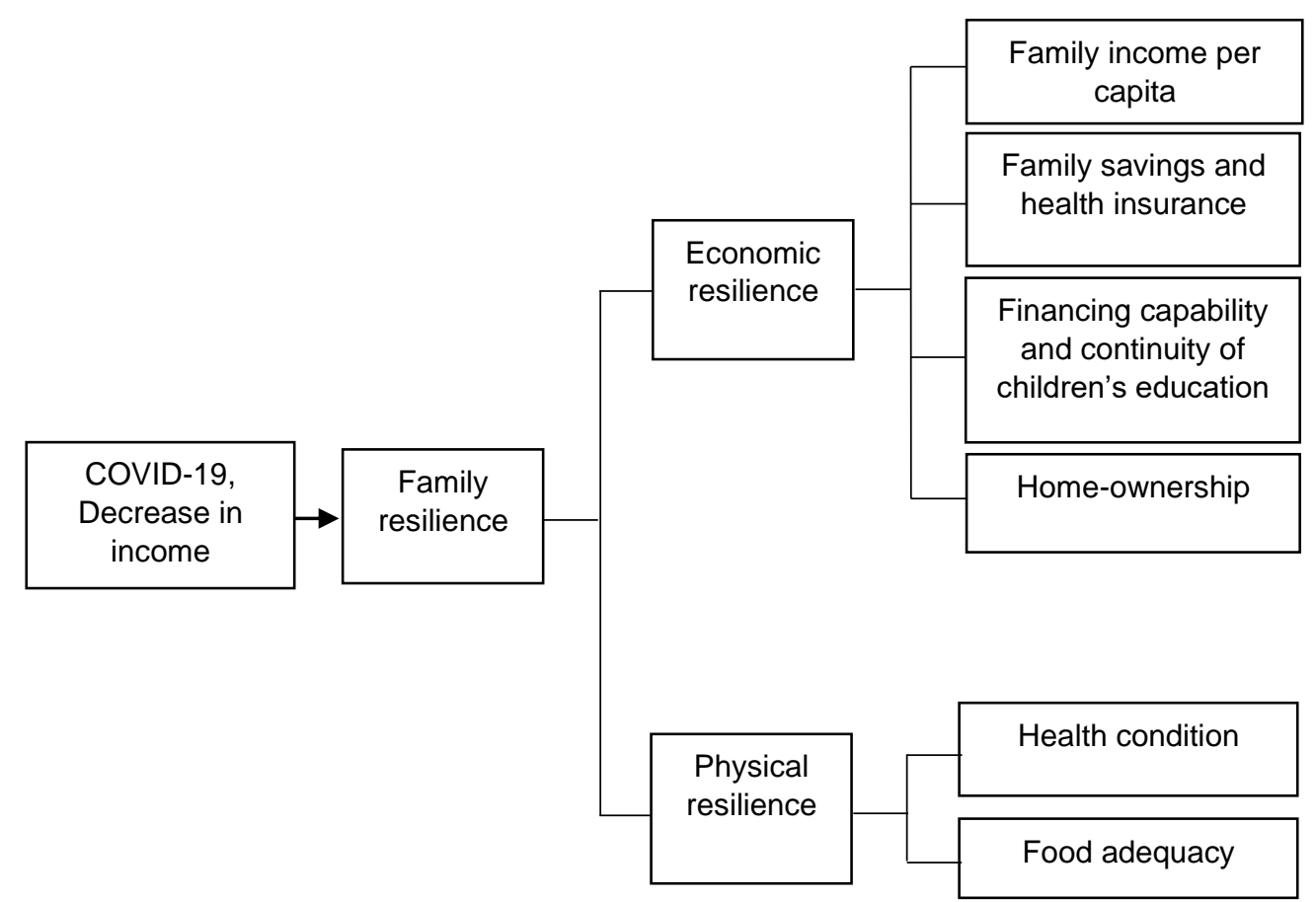

Source: Family resilience indicators of the Ministry of Empowerment, Women and Child Protection (KPPPA), Republic of Indonesia (2016)

Figure 1 Research framework 
Table 1 List of research variables

\begin{tabular}{|c|c|c|}
\hline Variable & Indicator & Definition \\
\hline \multirow{2}{*}{$\begin{array}{l}\text { The family income per } \\
\text { capita }\end{array}$} & The family income per capita & $\begin{array}{l}\text { Husband and/or wife have a fixed income per } \\
\text { month }\end{array}$ \\
\hline & Sufficient family income & $\begin{array}{l}\text { Household income is sufficient to meet their } \\
\text { daily needs }\end{array}$ \\
\hline \multirow{2}{*}{$\begin{array}{l}\text { Family savings and } \\
\text { health insurance }\end{array}$} & Family savings & Households have savings \\
\hline & Family health insurance & $\begin{array}{l}\text { Family members have Health insurance (BPJS } \\
\text { Health Card)/other }\end{array}$ \\
\hline \multirow{2}{*}{$\begin{array}{l}\text { Financing capability and } \\
\text { continuity of children's } \\
\text { education }\end{array}$} & $\begin{array}{l}\text { Ability to finance children's } \\
\text { education }\end{array}$ & $\begin{array}{l}\text { All household members are in school up to the } \\
\text { age of } 17-18 \text { years. Family incapacity includes } \\
\text { being in arrears in paying } \\
\text { contributions/children's educational needs }\end{array}$ \\
\hline & $\begin{array}{l}\text { Continuity of children's } \\
\text { education }\end{array}$ & $\begin{array}{l}\text { All members of the household (up to the age of } \\
17-18 \text { years) have not dropped out from } \\
\text { school/never been to school }\end{array}$ \\
\hline Homeownership & Homeownership & $\begin{array}{l}\text { Household ownership status of the building they } \\
\text { live in }\end{array}$ \\
\hline Health condition & Free from disease & Health condition during the Covid-19 pandemic \\
\hline \multirow{2}{*}{ Food adequacy } & Food adequacy & $\begin{array}{l}\text { All family members can eat a complete meal } \\
\text { (rice, vegetables, fish, tempeh/tofu, fruit) twice } \\
\text { per day }\end{array}$ \\
\hline & Nutritional adequacy & $\begin{array}{l}\text { There are family members who suffer from } \\
\text { nutritional problems (very thin or very fat or } \\
\text { stunted or cunt) }\end{array}$ \\
\hline
\end{tabular}

BPJS Health: Social Security Agency for Health (SSAH).

Source: The family resilience indicators of the Ministry of Empowerment, Women and Child Protection (KPPPA), Republic of Indonesia (2016)

\section{RESULT}

\section{Characteristics of Online Taxi Drivers}

Respondents had different experiences and duration of work before becoming online taxi drivers. Some of them also have to be far away from their families because their work location is outside Java. Respondents said that their previous working hours made it difficult for them to spend time with their families. In addition, the income received is also not commensurate with their work, plus when all respondents already have children where the need is increasing. To expect a higher income and flexible working hours, many drivers switching their previous job to online taxi drivers. Two informants said that previously online taxi drivers were only for side jobs, but when the work contract for their main job expired, they decided to make online taxi drivers as their primary job. Table 2 shows the characteristics of the respondents

\section{Family Economic Resilience on Online Taxi Driver}

Family Income per Capita. The first aspect is the family income per capita seen by comparing their income before and after becoming an online taxi driver (before the Covid-19 pandemic) and during the Covid-19 pandemic.

Table 2 Characteristics of online taxi drivers

\begin{tabular}{llcccc}
\hline \multicolumn{1}{c}{ Participants } & Gender & $\begin{array}{c}\text { Age } \\
\text { (years) }\end{array}$ & $\begin{array}{c}\text { Marital } \\
\text { Status }\end{array}$ & $\begin{array}{c}\text { Duration of Working } \\
\text { as an Online Driver, } \\
\text { years }\end{array}$ & $\begin{array}{c}\text { Work before } \\
\text { becoming an online } \\
\text { taxi driver }\end{array}$ \\
\hline $\begin{array}{l}\text { Online Taxi } \\
\text { Drivers (OTD) } 1\end{array}$ & Male & 32 & Married & 3 & $\begin{array}{l}\text { Event organizer } \\
\text { (outsourcing) }\end{array}$ \\
\hline $\begin{array}{l}\text { Online Taxi } \\
\text { Drivers (OTD) } 2\end{array}$ & Male & 34 & Married & 5 & $\begin{array}{l}\text { Printing field } \\
\text { (photocopy) }\end{array}$ \\
\hline $\begin{array}{l}\text { Online Taxi } \\
\text { Drivers (OTD) } 3\end{array}$ & Male & 32 & Married & 3 & $\begin{array}{l}\text { "Krapu" fish } \\
\text { cultivation }\end{array}$ \\
\hline $\begin{array}{l}\text { Online Taxi } \\
\text { Drivers (OTD) } 4\end{array}$ & Male & 24 & Married & 1 & Automotive sector \\
\hline
\end{tabular}


Table 3 Average total participant income

\begin{tabular}{lccc}
\hline \multicolumn{1}{c}{ Participants } & $\begin{array}{c}\text { Before becoming an } \\
\text { online taxi driver } \\
\text { (IDR/Month) }\end{array}$ & $\begin{array}{c}\text { After becoming an online taxi } \\
\text { driver before the pandemic } \\
\text { (IDR/Month) }\end{array}$ & $\begin{array}{c}\text { After becoming an } \\
\text { online taxi during the } \\
\text { pandemic }(\text { IDR/Month) }\end{array}$ \\
\hline $\begin{array}{l}\text { Online Taxi Drivers } \\
\text { (OTD) } 1\end{array}$ & 5 Million $(\$ 354.43)$ & 9 Million $(\$ 637.98)$ & $<1$ Million $(<\$ 70.89)$ \\
$\begin{array}{l}\text { Online Taxi Drivers } \\
\text { (OTD) } 2\end{array}$ & 2.1 Million $(\$ 148.86)$ & 8 Million $(\$ 567.09)$ & $<1$ Million $(<\$ 70.89)$ \\
$\begin{array}{l}\text { Online Taxi Drivers } \\
\text { (OTD) } 3\end{array}$ & 1.8 Million $(\$ 127.60)$ & 8 Million $(\$ 567.09)$ & $<1$ Million $(<\$ 70.89)$ \\
$\begin{array}{l}\text { Online Taxi Drivers } \\
\text { (OTD) } 4\end{array}$ & 4.3 Million $(\$ 304.81)$ & 7 Million $(\$ 496.21)$ & $<1$ Million $(<\$ 70.89)$ \\
\hline
\end{tabular}

Source: Data collection by researchers

They stated that their income increased after becoming an online taxi driver (Table 3). Before the Covid-19 pandemic, they drove online taxi all day long, and they were grateful for the increase in income. Furthermore, they admitted that at the beginning of becoming an online taxi driver, there were not many drivers in Jabodetabek, so they did not have many competitors in getting orders on the application.

During the Covid-19 pandemic, the income's decrease was drastic. The informant admitted that in a day, they only earn IDR 30,000 (\$2.13). This figure is far from their income before Covid-19. Their daily income can increase to around up to IDR 70,000 (\$4.96) from the tips given by the customer, even though the amount is uncertain. In a day, sometimes they get zero income. If accumulated, their incomes are only under IDR 1 million $(<\$ 70.89)$ in a month. This income decrease was due to the implementation of the LSSR, which limited people's mobility so that they experienced several obstacles. Usually, the informants can work full time from morning to evening, but work is hampered during the pandemic because of the small number of incoming orders. Informants admitted that they only get one to two orders and only five orders at most in a day. During the LSSR period, motorbike-based online taxi application services were limited to food and goods delivery. However, there was not a lot of food order due some people were afraid to order food using online. The work from home (WFH) scheme during the LSSR also reduces passenger services (to work and school), so car-based online taxis also experienced a decrease in income. In addition, the informant admitted that goods delivery services also declined because the users of these services are also usually work in offices.

Implementing the lockdown in some areas has forced online taxi drivers to take detours to deliver goods/food to customers. The average distance they have to travel to turn the road can reach 3 to $6 \mathrm{~km}$. It consumes more gasoline and time. It is in contrast with the minimum number of orders. Even when entering the delivery area to customers, the informants admit that they must spray them with disinfectant first. They also said some customers were afraid to take orders in person, so they had to use tools such as wood to place orders. Mostly the orders can only be delivered to the security post. During the pandemic, the decline in the informant's family income and the obstacles during the LSSR made it difficulties for them to meet their daily needs. The reduction in income reached 60-70 percent. The income decreases also affect their savings, burden their families, and impact to pay their installment.

Family Savings. The informants claim to save more after becoming online taxi drivers before the Covid-19 pandemic. As income increases, savings also increase significantly. Apart from saving money, one of them even renovated his house and gave part of his income to his parents so that their income was sufficient to meet their daily needs and installment. During the Covid-19 pandemic, especially after implementing the LSSR, they could not save even a little. Their income is only enough to meet their daily needs. They have installment expenses, including vehicles, electricity, and water bill. They claimed to be forced into arrears due to lack of income. One of the informants had to borrow money from moneylenders to pay the installment. If they didn't pay, the facilities would be revoked. Sometimes, they have no income at all, so they have to use their savings. The savings have been used to meet their daily needs during this pandemic. One of the informants said that he had to sell his motorbike to pay for the birth of his second child because there were no savings left. 
Financing Capability of Continuity of Children's Education and Family Health Insurance. Regarding the other installment, the researchers asked about the health insurance owned by the informants. The majority of them have National Health Insurance (NHI). Before the Covid-19 pandemic, they could pay for this health insurance regularly every month. However, two of the four informants were in arrears in their $\mathrm{NHI}$ payments during the Covid19 pandemic. As a result, some of theirs ended up being blocked. They admitted that they prioritized their family's daily needs rather than paying for NHI. Another aspect of family resilience being affected is financing capability to continue children's education. The Covid-19 pandemic has forced students to study online at home. Some of them have children who are already in school. All the informants' children in this study attend government-owned schools, where these schools are free of charge. However, with the learning from home scheme, the burden of online taxi drivers has increased to buy internet quota for online learning. Based on this study, the income decline of the informants does not directly affect the continuity of children's education. However, it impacts the additional expenses for purchasing internet quota and books.

The Homeownership. The following affected family's economic resilience is the homeownership. The homeownership of all the informants is a rented house, where they must pay rent every month. During the Covid-19 pandemic, they were forced to pay their rent in arrears. Two of them said that they had not paid their rent. Owners of rented houses only provide concessions for rent payments, which they can pay the late maximum for four months. They also have to borrow money from relatives to pay rent immediately. One of them, who lives alone in Jakarta, even left his rented house because his income was not enough to pay, and he had to stay in a friend's shop for almost two months. The decline in income that occurs in online taxi drivers impacts the sustainability of house rental installment.

\section{Family Physical Resilience on Online Taxi Driver}

Food Adequacy and Nutrition. The informants claim that no one has been diagnosed with Covid-19 during the pandemic. However, they often feel uncomfortable, such as fatigue and fever, due to working from morning to night to get more income. They always maintain health protocols following government regulations when working outside the home, wearing masks, and using hand sanitizer regularly. Every time they want to pick up, they will spray the vehicles first and provide masks and hand sanitizers for the passengers. They always take care of their health because they are aware that they are the head of the family, who is obliged to support them. If they are sick, no one can earn any more income, especially during the Covid-19 pandemic.

Another aspect of family physical resilience is the fulfillment of daily food needs. The decline in income during the Covid-19 pandemic has affected their families' fulfillment of food purchases. They need to be much more economical in buying food during the pandemic. They can only hope for boxed rice distributed on the streets, where they will take them home to give to their families. They are even reluctant to eat the rice box even though they have not eaten anything since the morning. They wish their families could eat it comfortably. To meet their food needs, they also rely on government social assistance in a package of essential goods or vouchers from the office to be used at minimarkets for primary needs. They must borrow money from their relatives to meet their food needs. However, they admit that none of their families have been diagnosed with nutritional problems, such as being very underweight. But they are worried about their family's nutritional problems, especially at pandemic when the nutritional intake decreases both in quantity and quality. They only eat one or two side dishes and rarely eat fruit.

\section{Transitional LSSR Period}

The informants claim that no one has been diagnosed with Covid-19 during the pandemic. However, they often feel uncomfortable, such as fatigue and fever, due to working from morning to night to get more income. They always maintain health protocols following government regulations when working outside the home, wearing masks, and using hand sanitizer regularly. Every time they want to pick up, they will spray the vehicles first and provide masks and hand sanitizers for the passengers. They always take care of their health because they are aware that they are the head of the family, who is obliged to support them. If they are sick, no one can earn any more income, especially during the Covid-19 pandemic.

Another aspect of family physical resilience is the fulfillment of daily food needs. The decline in income during the Covid-19 pandemic has affected their families' fulfillment of food purchases. They need to be much more 
economical in buying food during the pandemic. They can only hope for boxed rice distributed on the streets, where they will take them home to give to their families. They are even reluctant to eat the rice box even though they have not eaten anything since the morning. They wish their families could eat it comfortably. To meet their food needs, they also rely on government social assistance in a package of essential goods or vouchers from the office to be used at minimarkets for primary needs. They must borrow money from their relatives to meet their food needs. However, they admit that none of their families have been diagnosed with nutritional problems, such as being very underweight. But they are worried about their family's nutritional problems, especially at pandemic when the nutritional intake decreases both in quantity and quality. They only eat one or two side dishes and rarely eat fruit.

\section{DISCUSSION}

Online taxi drivers' income had significantly increased compared to their job before becoming online taxi drivers. The reason was the public loves applications that make transportation easier. The people warmly welcomed this application's presence, considering the ease of ordering and the practicality of use. Also, the security in this application can be accounted for, and the costs that tend to be cheap made online taxi drivers increasingly skyrocket and needed (Purbohastuti, 2018; Ratu, 2020). This is indicated by the number of application downloaders in the millions (Natadjaja \& Setyawan, 2016; Sonhaji, 2018). The current online-based mode of transportation is one of the solutions to overcome unemployment. The community has real benefits (Hartanto \& Tajsgoani, 2020). This study shows that informants made online taxi drivers their primary job, and since becoming online drivers, their income has increased almost 80 percent. This is in line with Walandouw, Primaldhi, Wisana, and Nugroho (2018), which show the income of online taxi drivers in Medan has increased after joining an online taxi driver. The average monthly income of online taxi drivers in Medan is also higher than the minimum wage cities/regencies in Medan in 2018. Online taxi driver's technology also significantly increases online taxi drivers' income in Cimahi City (Fakhriyah, 2020). However, the Covid-19 pandemic has impacted Indonesia's economy on online taxi drivers as independent workers (Walandouw, Wisana, \& Primaldhi, 2020).
The Covid-19 pandemic paralyzed people's socioeconomic conditions in Indonesia, especially in several areas (Budastra, 2020; Iswari, Saragi, Sirait, \& Putra, 2020). The government's LSSR policy, which prohibits carrying passengers, must be implemented due to several considerations. First, online taxi drivers can become contracting Covid-19 from positively infected passengers. Second, they can become a virus carrier, both from the passengers and the goods that the driver delivers. Third, online taxi drivers who have contracted Covid-19 can also transmit it to passengers (Hartanto \& Tajsgoani, 2020). Work from home scheme for workers and school from home (SFH) scheme for students decrease online taxi passenger's number. They must compete each other to get a part of this small number of passengers. Hadiwardoyo (2020) found that online taxi drivers complained about a 70 percent reduction in passengers, so most of them choose to take a break from operations or go home. The results of in-depth interviews show that the Covid-19 pandemic through the implementation of the LSSR has affected the resilience of online taxi driver families both from an economic and social perspective. Decreased income is also in line with Eddy and Harahap (2020), which states there has been a decrease in the number of receipts (IDR) of online taxi drivers due to social distancing ranging from 5.3 to -87.5 percent with an average value $=-$ 58.14 percent. Covid-19 is a significant problem for Indonesia due to the big impacts. There are many losses, including a decrease in online taxi driver income. It impacts the Indonesian economy where a country's economic development aims to achieve community prosperity through economic growth and evenly distributed income (Iswari, Saragi, Sirait, \& Putra, 2020). Indonesian economy also relies on the sustainability economy of informal sectors as well as the online taxi's sector.

The resilience of the online taxi driver family is also affected by the decline in income during the Covid-19 pandemic. Fortunately, the Covid19 pandemic has not affected the resilience of online taxi driver families in the aspect of the sustainability of children's schools. The drivers had bought the quota independently. In addition, the government, especially the Ministry of Education and Culture, collaborated with ministries and mobile operators from September to December 2020 allocated internet data quota assistance for students and educators (Ministry of Education and Culture, 2020). This is aimed to facilitate students and educators to continue to carry out online 
learning during this pandemic. The learning quota is expected to reduce the burden of students and educators in carrying out online learning (Ministry of Education and Culture, 2020). From family savings, with the WFH policy, online taxi drivers do not have savings because their income has decreased drastically, and their economy is threatened (Tuti, 2020). The savings function is to provide funds quickly when an unpredictable condition occurs (Sina, 2020). However, family savings owned by online taxi drivers before the Covid19 pandemic were used and they have no more savings. This is a threat to their family's resilience if something unpredictable happens in the future. Other issue, the resilience of the online taxi driver family from family health insurance is also affected by the Covid-19 pandemic. The inability of online taxi drivers to pay National Health Insurance (NHI) dues is caused by decreased income. This is in line with the Rosmanely (2018) study found that low income can reduce the community's frequency of paying NHI contributions. Arfiliyah's research (2016) also states that the monthly average income and expenditure have a significant relationship to the regularity of paying contributions to independent participants of $\mathrm{NHI}$. Another issue is the homeownership. Families who have occupied their own houses are expected to have relatively better economic resilience (Hasmira, Media, \& Andrefson, 2018). The majority of online taxi drivers do not yet have their homeownership. From an economic perspective, family resilience for online taxi driver's homeownership variable is still low.

The decline in income of online taxi drivers during the Covid-19 pandemic threatens the resilience of their families in meeting their daily food needs. They are doubt about their families' nutritional status, especially during this pandemic. They consume low nutritional food and they also wish for other's help. Nutritious food should be very much needed in maintaining the health of online taxi drivers and their families during the Covid-19 pandemic. Kurniasih (2020) shows that expenditure on food consumption is reduced. They have to adjust to the income earned. Without adequate income support, the need for nutritious food consumption to increase body immunity is impaired (Sina, 2020). Adequate food and good nutritional status for all family members must be considered in forming a family with good physical resilience (Central Statistics Agency \& Ministry of Women's Empowerment and Child Protection, 2016). Lack of food and nutrition intake can make a person more susceptible to various health problems and diseases (Central Statistics Agency \& Ministry of Women's Empowerment and Child Protection, 2016). Online taxi driver jobs have a high health risk during this Covid-19 pandemic, and they can easily get Covid-19. They are forced to continue to work and interact with other passengers/people. Online taxi drivers will do whatever it takes for their families to stay alive during the Covid-19 pandemic. The various needs of the community at home require solutions to access and obtain the items needed. This condition is momentum to strengthen the use of online taxi driver applications (Taufik \& Ayuningtyas, 2020). However, many barriers happen during the pandemic. In Medan City, there was a decrease in online taxi driver activity i.e., the number of orders per day due to social distancing (Eddy \& Harahap, 2020).

Economic pressures during the Covid-19 pandemic affect the resilience of online taxi drivers' families. This is in line with Sukmawati and Puspitawati (2021) research that there is a significant negative effect between economic pressure and family resilience and a significant positive impact on the husband's income. This means that the lower the financial pressure faced by the family, the higher the family's resilience and the higher the husband's income, the better the family's resilience. The Covid-19 pandemic has impacted economic resources, especially those working in the informal sector, while still working for families. Their economic conditions will become more difficult if they do not have sufficient savings to meet their needs (Kasdi \& Saifudin, 2020).

\section{CONCLUSION AND SUGGESTION}

The resilience of online taxi driver families is greatly affected by the Covid-19 pandemic, both in terms of economic and physical resilience. The LSSR implementation and the policy restricting two-wheeled transportation activities resulted in a drastic decrease in online taxi drivers' income, which directly impacted their families' economic and physical resilience. Some economic resilience indicators have not even been fulfilled during the pandemic, and the adequacy of food and nutrition depends on the various income earned. Identifying family resilience in online taxi drivers can illustrate the family's resilience as the smallest societal unit when facing situations. Good family resilience will have implications for national development. These efforts are needed to increase family resilience to reduce or overcome various problems that hinder national development, 
especially in Indonesia, focusing on economic recovery due to the Covid-19 pandemic.

In this case, considering Covid-19 is still a pandemic in Indonesia, cooperation between online taxi drivers and companies must be appropriately maintained. The company's social assistance to online taxi drivers has proven to be very helpful. Besides that, companies can create a new program innovation in helping online taxi drivers' health insurance arrears, such as modify the minimum points requirements to the online taxi driver. Furthermore, companies or governments can create entrepreneurial training programs aimed at online taxi driver wives to increase income and meet daily needs to maintain family resilience. This study has limitations, including the number of informants is small, the coverage area is limited to urban and suburban areas (Jakarta, Bogor, Depok, Tangerang, Bekasi areas), and the indicators studied are only on the socio-economic side of family indicators that are listed in the Guidelines for Family Resilience of the Ministry of Women's Empowerment and Child Protection.

\section{ACKNOWLEDGMENT}

The authors would like to thank JSPS KAKENHI Grant Number $19 \mathrm{H} 02325$ and Universitas Indonesia International Indexed Publication (PUTI) Grant 2020 No. NKB5042/UN2.RST/HKP.05.00/2020.

\section{REFERENCES}

[BPS \& Kemen PPPA] Badan Pusat Statistik \& Kementerian Pemberdayaan Perempuan dan Perlindungan Anak. (2016). Building family resilience. Jakarta, ID: Ministry of Women's Empowerment and Child Protection

[BPS Provinsi Jakarta] Badan Pusat Statistik Provinsi DKI Jakarta. (2020). Total population of DKI Jakarta Province aged over 15 years by type of activity during the past week and gender 2018-2020. Jakarta, ID: Central Statistics Agency DKI Jakarta Province

Budastra, I. K. (2020). Dampak sosial ekonomi Covid-19 dan program potensial untuk penanganannya: Studi kasus di Kabupaten Lombok Barat. Jurnal Agrimansion, 20(1), 48-57.

doi: 10.29303/agrimansion.v21i1.321

Dewi, M. M., Magdalena, F., Ariska, N. P. D.,
Setiyawati, N., \& Rumboirusi, W. C. B. (2020). Dampak pandemi covid-19 terhadap tenaga kerja formal di Indonesia. Populasi, 28(2), 32-53. doi: 10.22146/jp.63345

Eddy, \& Harahap, U. N. (2020). Pemberlakuan work from home (WFH) dan dampak ekonominya bagi pengemudi ojek online. Jurnal Simetri Rekayasa, 2(1), 65-71. Retrieved from https://jurnal.harapan.ac.id/index.php/JSR/ article/view/156/82

Erlingsson, C., \& Brysiewicz, P. (2017). A hands-on guide to doing content analysis. African Journal of Emergency Medicine, 7(3), 93-99.

Fahlefi, R., Ahmad, S., \& Rizal. (2020). Dampak pandemi Covid-19 terhadap perekonomian masyarakat di sektor informal. Jurnal Imara, 4(2), 158-167. doi: 10.31958/imara.v4i2.2379

Fakhriyah, P. (2020). Pengaruh layanan transportasi online (Gojek) terhadap perluasan lapangan kerja bagi masyarakat di Kota Cimahi. Comm-Edu (Community Education Journal), 3(1), $34 . \quad$ doi: 10.22460/comm-edu.v3i1.3719

Farida, I., Tarmizi, A., \& November, Y. (2016). Analisis pengaruh bauran pemasaran $7 \mathrm{P}$ terhadap kepuasan pelanggan pengguna Gojek online. Jurnal Riset Manajemen dan Bisnis (JRMB) Fakultas Ekonomi UNIAT, 1(1), 31-40. doi: 10.36226/jrmb.v1i1.8

Governor of the Special Capital Region of Jakarta Province. (2020). Regulation of the Governor of the Special Capital Region of Jakarta Number 33 of 2020 concerning implementing large-scale social restrictions in handling Coronavirus Disease 2019 (Covid-19) in the Province of the Special Capital Region of Jakarta. DKI Jakarta, Indonesia: Governor of the Special Capital Region of Jakarta Province

Hadiwardoyo, W. (2020). Kerugian ekonomi nasional akibat pandemi covid-19. Journal of Business and Entrepreneurship (BASKARA) Universitas Muhammadiyah Jakarta, 2(2), 83-92. doi: 10.24853/baskara.2.2.83-92

Hartanto \& Tajsgoani, N. (2020). Dualisme pengaturan ojek online angkut penumpang dalam Pembatasan Sosial Berskala Besar (PSBB) di Jakarta. IAIN Kendari, 13(2), 253-267 
Hasmira, M. H., Media, Y., \& Andrefson, E. (2018). Survey Ketahanan Keluarga di Provinsi Sumatera Barat. West Sumatra, Indonesia: Research and Development Agency of West Sumatra Province

Iswari, I., Saragi, R. A., Sirait, R. R., \& Putra, W. (2020). Analisis perbedaan pendapatan driver Go-jek sebelum dan saat terjadi pandemi covid-19 di Kota Medan. Al-Sharf Jurnal Ekonomi Islam, 1(1), 94-102. doi: 10.30596/al-sharf.v1i1.42

[Kemendikbud] Kementerian Pendidikan dan Kebudayaan. (2020, September 25). Kemendikbud resmikan kebijakan bantuan kuota data internet 2020. Retrieved from https://www.kemdikbud.go.id/main/blog/20 20/09/kemendikbud-resmikan-kebijakanbantuan-kuota-data-internet-2020

Ministry of Health. (2020). Covid-19 dalam angka. Retrieved from https://www.kemkes.go.id/

Nugraha, A. R. (2020, April 9). Online taxi driver organization: There is 4 million online taxi driver in Indonesia. Kumparan. Retrieved from https://kumparan.com/kumparantech /organisasi-ojol-ada-4-juta-driver-ojol-diindonesia-1tBrZLEXOEl/full

Kasdi, A., \& Saifudin, S. (2020). Resilience of muslim families in the pandemic era: Indonesian millennial muslim community's response against Covid-19. Jurnal Penelitian, 81-94.

Kurniasih, E. P. (2020). Dampak pandemi covid 19 terhadap penurunan kesejahteraan masyarakat Kota Pontianak. In Prosiding Seminar Akademik Tahunan IImu Ekonomi dan Studi Pembangunan (SATIESP) 2020, 277-289. Retrieved from https://feb.untan.ac.id/wpcontent/uploads/2020/12/Erni-1.pdf

Natadjaja, L., \& Setyawan, P. B. (2016). Creating community through design: The Case of Gojek online. IJCCI - International Journal of Cultural and Creative Industries, 4(1), 18-27. Retrieved from http://repository.petra.ac.id/17475/

Ngadi, N., Meliana, R., \& Purba, Y. A. (2020). Dampak pandemi covid-19 terhadap PHK dan pendapatan pekerja di Indonesia. Jurnal Kependudukan Indonesia, 43-48. doi: 10.14203/jki.v0i0.576

Pratiwi, A. N. (2016). Faktor yang mempengaruhi keteraturan membayar iuran pada peserta jaminan kesehatan nasional (JKN) kategori peserta mandiri (Studi kasus pasien rawat inap Rumah
Sakit dr. Soebandi Kabupaten Jember) (Undergraduate Thesis, Universitas Jember, Indonesia). Retrieved from https://repository.unej.ac.id/bitstream/handl e/123456789/73503/112110101084--

Arfiliyah\%20Nur\%20Pratiwi-180.pdf?sequence $=1$

Purbohastuti, A. W. (2018). Faktor penyebab beralihnya konsumen ojek pangkalan menjadi ojek online. Tirtayasa Ekonomika, 13(2), 238-251. doi: 10.35448/jte.v13i2.4306

Buana, A. R. (2020). Problematika regulasi ojek online dalam masa pembatasan sosial berskala besar covid-19. Adalah Buletin Hukum \& Keadilan, 4(1), 137-144. doi: 10.15408/adalah.v4i1.15574

Rahmadana, M. F., \& Sagala, G. H. (2020). Economic resilience dataset in facing physical distancing during Covid-19 global pandemic. Data in brief, 32, 106069.

Rosmanely, S. (2018). Studi ketidakpatuhan membayar iuran BPJS Kesehatan peserta non PBI bukan penerima upah di Kelurahan Parang Tambung Kec. Tamalate (Thesis, Universitas Hasanuddin, Makassar, Indonesia). Retrieved from http://digilib.unhas.ac.id/uploaded_files/tem porary/DigitalCollection/MGNjYTEyN2ZiYjl 4YzljNWE2ZGM0ODZkMTdhNjNINDM4Yj Q3MDg4ZA==.pdf

Sina, P. G. (2020). Ekonomi rumah tangga di era pandemi covid-19. Journal of Management: Small and Medium Enterprises (SMEs), 12(2), 239-254. doi: 10.35508/jom.v12i2.2697

Sonhaji. (2018). Aspek hukum layanan ojek online perspektif Undang-Undang Nomor 13 Tahun 2003 tentang Ketenagakerjaan. Administrative Law \& Governance Journal, 1(4), 371-385. doi: 10.14710/alj.v1i4.371385

Sukmawati, I \& Puspitawati. (2021). Pengaruh tekanan ekonomi dan peran gender terhadap ketahanan keluarga selama masa pandemi Covid-19. (Skripsi). IPB University.

https://repository.ipb.ac.id/handle/1234567 89/107791

Suprayogaswara, D. (2017). Analisis faktorfaktor yang mempengaruhi produktivitas tenaga kerja gojek di Kota Malang. Jurnal IImiah Mahasiswa FEB Universitas Brawijaya, 6(1), 1-12. Retrieved from https://jimfeb.ub.ac.id/index.php/jimfeb/arti cle/view/4400 
Taufik, \& Ayuningtyas, E. A. (2020). Dampak pandemi Covid 19 terhadap bisnis dan eksistensi platform online. Jurnal Pengembangan Wiraswasta, 22(01), 2132. doi: 10.33370/jpw.v22i1389

Tuti, R. W. (2020). Analisis implementasi kebijakan work from home pada kesejahteraan pengemudi transportasi online di Indonesia. Transparansi: Jurnal IImiah IImu Administrasi, 3(1), 73-85. doi: 10.31334/transparansi.v3i1.890

Walandouw, P., Primaldhi, A., Wisana, I. D. G. K., \& Nugroho, A. H. (2018). Dampak GOJEK terhadap Perekonomian
Yogyakarta pada Tahun 2018. Lembaga Demografi FEB UI. Retrieved from https://ldfebui.org/wp-content/uploads/ 2019/03/LDUI-Dampak-GOJEK-padaPerekonomian-Yogyakarta-2018.pdf

Walandouw, P., Wisana, I. D. G. K., \& Primaldhi, A. (2020). Laporan Penelitian Survey pengalaman mitra driver Gojek selama pandemi covid-19. Lembaga Demografi FEB UI. Retrieved from https://ldfebui.org/wp-content/uploads/ 2020/06/Laporan-Penelitian-SurveiPengalaman-Mitra-Driver-Gojek-SelamaPandemi-Covid19.pdf 